\title{
DIRECT SHEAR RESISTANCE MODELS FOR SIMULATING BURIED RC ROOF SLABS UNDER AIRBLAST-INDUCED GROUND SHOCK
}

\author{
Theodor Krauthammer ${ }^{1 *}$ and Serdar Astarlioglu ${ }^{2}$ \\ ${ }^{1}$ Center for Infrastructure Protection and Physical Security, University of Florida, PO Box \\ 116580, Gainesville, FL 32611-6580, USA;tedk@ufl.edu, * Corresponding author \\ ${ }^{2}$ Hinman Consulting Engineers, Inc., 1800 Diagonal Road, Suite 525, Alexandria, Virginia \\ 22314, USA; Serdar@hce.com
}

\section{Abstract}

Direct shear is a known response mechanism in Reinforced concrete (RC) slabs subjected to blast loads that may cause their sudden and catastrophic failure. It poses a very serious hazard to facilities subjected to blast. The empirical equations defining the direct shear resistance function for RC elements were developed in the 1970s based on results from a limited number of static tests. These equations have been used for the analyses of structural response under blast and ground shock effects since the 1980s. However, the direct shear mechanism in the short-duration dynamic domain has not been sufficiently studied, and it was not clear if those models are accurate. New static and impact test data from shear specimens with three reinforcement ratios were used to derive modified direct shear resistance functions that were different from the resistance functions proposed in the 1970s. One must determine if the new resistance functions could accurately represent the behavior of RC slabs subjected to blast loads. Furthermore, one had to understand the behavioral differences in the numerical simulations that could be associated with the two types of resistance functions, and provide recommendations on how to most appropriately represent direct shear in such analyses. This paper is focused on the assessment of the new direct shear resistance functions in RC, and the results from the parametric study were compared results obtained with the previous empirical direct shear model and with precision field test data to provide conclusions and 
recommendations.

Key words: Direct Shear, Reinforced Concrete, Buried Slabs, Airblast-induced, Ground Shock

\section{Introduction}

Most structural engineers are familiar with the effects of shear in reinforced concrete (RC) flexural elements, such as beams. That shear problem has been extensively studied, and it was shown that for ductile beams (where failure is governed by rupture of the tensile reinforcement) diagonal cracks develop below the neutral axis of the beam, along directions defined by the principle stress field, as described in [1]. Because of the diagonal cracks and tensile reinforcement failure, this type of shear is termed 'diagonal tension', it is related to changes in the flexural moment along the beam, and various recommendations have been adopted for shear reinforcement along such a beam to resist its effects [1]. However, there is another type of shear failure that has been noticed in structural concrete loaded statically that could appear near locations of geometric discontinuities, where the cracks are perpendicular to the axis of the member, and where no flexural behavior is present [2-5]. This type of shear behavior is termed 'direct shear', it is related to a shearing action along a shear plane, where the loaded member slides along the supporting members, as illustrated in Fig. 1.

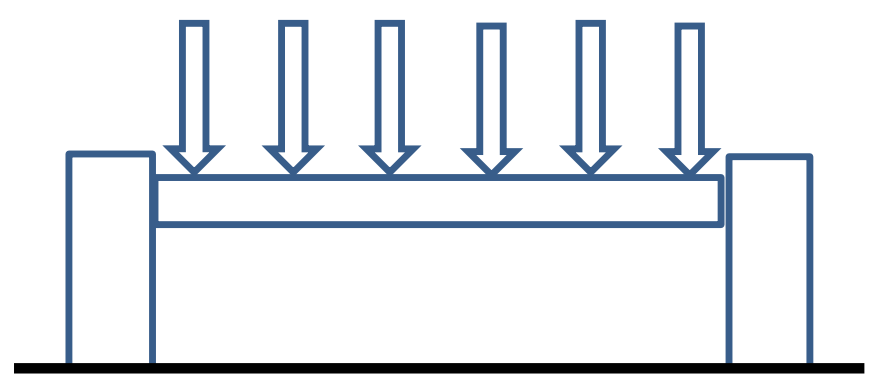

Fig. 1: Direct shear behavior 


\section{Objectives and Scope}

Direct shear is a known structural response mechanism in RC slabs subjected to blast loads that may cause their sudden and catastrophic failure. This response poses a very serious hazard to protected facilities subjected to blast. Empirical resistance functions for direct shear in RC elements were introduced in the 1970s, based on a limited number of static tests, and their empirical adaptation for the analyses of structural response under blast and ground shock effects has been used since the 1980s. However, the direct shear mechanism in the shortduration dynamic domain has not been sufficiently studied, and it is not clear if those models are accurate. New static and impact tests on RC direct shear specimens with three reinforcement ratios provide results that were used to derive modified direct shear resistance functions that were different from the resistance functions proposed in the 1970s. This enabled one to study the behavioral differences in the numerical simulations that could be associated with the two types of resistance functions, and provide recommendations on how to most appropriately represent direct shear in such analyses. The two direct shear models were used for the analysis of RC roof slabs subjected to airblast-induced ground shock that were tested in the 1980s, and the results were compared to understand the effects of the direct shear models on numerical simulations.

\section{Background}

The studies reported in [2-4] focused primarily on direct shear specimens with reinforcement across the shear plane (Fig. 2) to develop a better understanding of the shear strength, and its relationship with material and geometric properties of the specimens. The parameters studied included the effects of shear strength on uncracked and pre-cracked specimens, reinforcement ratios and spacing, concrete strength, application of stresses parallel and transverse to the shear plane, and the influence of dowel action in the reinforcement, as summarized in [5]. 


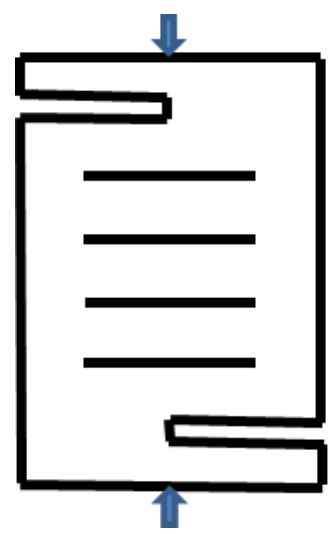

Fig. 2: Direct shear test specimen

It was found that the shear slip required to diminish the shear strength did not exceed the reinforcing bar diameter across the shear plane, and that the existence of cracks reduced the ultimate shear capacity and increased relative slip. Changing the reinforcement size and spacing affected the shear strength, while reducing the concrete strength set an upper limit beyond which changes to the reinforcement parameter had a lesser effect on shear resistance. Below this upper limit, the shear strength of pre-cracked specimens primarily depended on friction. Externally applied compressive stresses transverse to the shear plane increased the direct shear resistance of both cracked and uncracked specimens by reducing the crack width and enhanced both friction and aggregate interlock. The accompanying theoretical work showed a relationship between the observed shear strength and the formation of a truss-like mechanisms that consisted of diagonal concrete struts in compression between diagonal cracks along the shear plane, and tension and dowel action in the transverse reinforcement. Consequently, an empirical model for direct shear, based on those early studies was proposed by Hawkins [6], that was incorporated into several reports on addressing direct shear in protective structures [7-9], as will be described later, herein. Additional efforts to study direct shear are described in [10-13] that included both precision tests on the same type of specimens, as shown in Fig. 2, and theoretical studies focused on obtaining shear stress vs. shear slip 
relationship along the shear plane. Although a study reported in [12] included both static and dynamic tests, the dynamic loads were applied by a servo-controlled actuator and the triangular load pulse reached its peak after 35 to 55 milliseconds. As will be shown later, herein, this loading rate was too slow to represent the direct shear phenomenon observed in either blast impact tests. Therefore, most of those earlier studies addressed only the behavior in the static domain, and they did not enable one to develop an accurate characterization of direct shear behavior under short-duration dynamic loads.

The effects of direct shear on structures subjected to blast effects was shown in [14] with field tests on shallow-buried box-type structures that included two test cases with direct shear failures. The direct shear phenomenon was also studied in [15], and reinforced concrete roof slabs exhibited direct shear responses under severe airblast-induced ground shock loading. Direct shear produced a vertical failure plane at the edge of the roofs, and both the top and bottom steel exhibited necking prior to being severed nearly flush with the failure plane. Several theoretical and numerical studies were carried out previously [16-21] to investigate the behavior of direct shear in structural concrete systems subjected to blast, with a particular attention to the test structures used in [14,15]. The studies in [16,18-20] employed a Timoshenko beam approach with a shear failure criterion to characterize the sequence of flexural and localized shear behaviors that could lead to a better understanding of the observed responses during the tests. The studies in $[17,21]$ employed a single-degree-of-freedom (SDOF) approach that operated on two loosely-coupled systems, one for the flexural response and one for the direct shear response, to study the same structures that were tested in $[14,15]$. The direct shear resistance function used in those studies was based on the empirical model proposed and described in [6-9]. The original model from [6-9] (the dashed segmental curve in Fig. 3) was modified in [17] by applying an enhancement factor of 1.4 to account for the effects 
of in-plane compression and rate effects that were not considered in the static model, as shown by the solid segmental curve in Fig. 3.

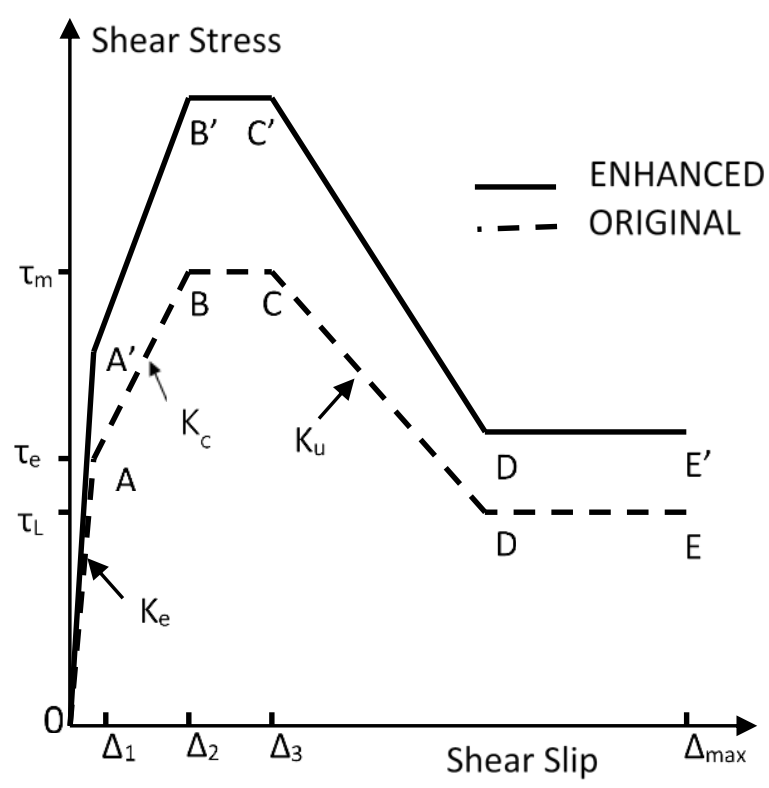

Fig. 3: Original and modified direct shear models [17]

The original Hawkins model [6-9] utilized a piecewise-linear approach to relate direct shear strength and corresponding shear slip values, as obtained experimentally. The slip values $\Delta_{1}$, $\Delta_{2}$, and $\Delta_{3}$ define the slip at Points A, B, and C that correspond to the shear strengths $\tau_{\mathrm{e}}$ and $\tau_{\mathrm{m}}$. $\tau_{\mathrm{e}}$ is the shear strength at the end of the elastic range, and $\tau_{\mathrm{m}}$ is the maximum shear strength. $\tau_{\mathrm{L}}$ is the residual shear strength between Points $\mathrm{D}$ and $\mathrm{E}$ that terminates at the maximum slip $\Delta_{\max }$. $\mathrm{K}_{\mathrm{e}}$ is the elastic slope, $\mathrm{K}_{\mathrm{c}}$ is the post-cracking slope, and $\mathrm{K}_{\mathrm{u}}$ is the slope of the direct shear strength beyond the peak value. The different segments of these models are defined later, herein.

Although those theoretical and numerical studies showed very good agreement with the observed structural behaviors during the field test in $[14,15]$, no test data were recorded that could be used to characterize the direct shear behavior in the dynamic domain. Therefore, direct shear was not been fully understood, due to the lack of precision direct shear test data that could 
be used to characterize such behavior for both static and dynamic loading environments. Furthermore, since no adequate precision test data existed from short duration dynamic tests on direct shear specimens, it was not clear if the empirical understanding of this critical phenomenon was correct. Therefore, additional precision static and impact test data were required for the derivation of direct shear resistance models in reinforced concrete specimens.

\section{Precision Test Data for Direct Shear}

The direct shear problem under both static and impact effects was addressed again in [22-25] to obtain precision test data for a comprehensive assessment of the previously-published models. The direct shear behavior was investigated using uncracked push-off specimens, as shown in Fig. 4 and defined in Tables 1 and 2.

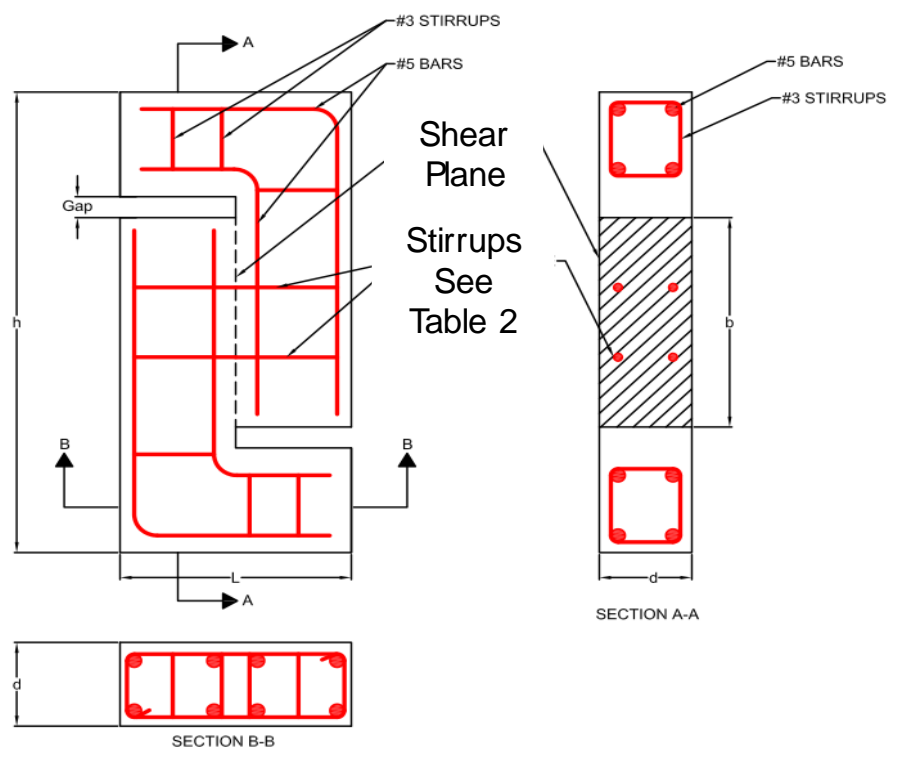

Fig. 4: Push-off specimen geometry

Table 1. Push-off specimen geometry

\begin{tabular}{ccccccc}
\hline Specimen Dimensions & $\begin{array}{c}\mathrm{L} \\
(\mathrm{mm})\end{array}$ & $\begin{array}{c}\mathrm{h} \\
(\mathrm{mm})\end{array}$ & $\begin{array}{c}\mathrm{d} \\
(\mathrm{mm})\end{array}$ & $\begin{array}{c}\mathrm{b} \\
(\mathrm{mm})\end{array}$ & $\begin{array}{c}\text { Gap } \\
(\mathrm{mm})\end{array}$ & $\begin{array}{c}\text { Shear Plane } \\
\text { bd }\left(\mathrm{mm}^{2}\right)\end{array}$ \\
\hline 292 & 635 & 140 & 254 & 25 & 35484 \\
\hline
\end{tabular}


Table 2. Reinforcement tensile strength and concrete compressive strength

\begin{tabular}{cccccc}
\hline $\begin{array}{c}\text { Specimen } \\
\text { Series }\end{array}$ & $\begin{array}{c}\mathrm{f}^{{ }^{*}} \\
(\mathrm{MPa})\end{array}$ & $\begin{array}{c}\mathrm{f}_{\mathrm{y}} \\
(\mathrm{MPa})\end{array}$ & $\begin{array}{c}\text { Reinforcement } \\
\text { Ratio, } \rho\end{array}$ & $\begin{array}{c}\text { Number of } \\
\text { Stirrups }\end{array}$ & Stirrup Size \\
\hline NC-1-0 & 31 & 414 & $0.0 \%$ & 0 & NA \\
NCS-1-1 & 31 & 414 & $0.8 \%$ & 4 & $\# 3$ \\
NCS-1-2 & 31 & 414 & $1.6 \%$ & 8 & $\# 3$ \\
\hline
\end{tabular}

* f c was obtained from tests on $\Phi 6 " X 12 "(\Phi 150 \mathrm{~mm}$ X $300 \mathrm{~mm})$ cylinders.

Twelve static and 17 impact tests were done on normal strength concrete (NSC) specimens in [22-23] (many more tests were conducted on ultra-high performance concrete specimens with the same set of geometric and reinforcement configurations, but those results are outside the scope of this paper). Two Keyence H157 Hi-Accuracy lasers were mounted in a custom-built steel housing for protection, and used to measure the displacements of two aluminum tabs that were mounted on both sides of the shear plane. These displacements were used to derive the relative shear slip between the two sides of the shear plane. Impact tests of the NC-1-0 specimens were conducted using a small drop hammer with a mass of $340 \mathrm{~kg}$ dropped from a height of up to $3.5 \mathrm{~m}$. This hammer could not generate enough energy to fail the specimens with the higher shear capacity contributed by the stirrups, and a larger drop hammer capable of dropping a $2592 \mathrm{~kg}$ striker with a maximum drop height of about $7 \mathrm{~m}$ was used to test those specimens (however, a maximum drop height of $1.524 \mathrm{~m}$ was used in the tests). A $3114 \mathrm{kN}$ load cell was used to measure the impact force vs. time in all impact tests. Table 3 shows a summary of average peak shear stresses for static and impact tests that also shows direct shear strength enhancement by the load rate.

Table 3. Approximate static and dynamic shear strength for normal strength concrete

\begin{tabular}{|c|c|c|c|c|}
\hline \multirow[t]{2}{*}{$\begin{array}{l}\text { Specimen } \\
\text { Series }\end{array}$} & \multirow[t]{2}{*}{$\rho(\%)$} & \multicolumn{2}{|c|}{$\begin{array}{l}\text { Avg. Peak Shear Stress } \\
(\mathrm{MPa})\end{array}$} & \multirow{2}{*}{$\begin{array}{c}\text { Dynamic/Static } \\
\text { Load Ratio } \\
(\mathrm{D} / \mathrm{S})\end{array}$} \\
\hline & & Dynamic & Static & \\
\hline NC-1-0 & 0 & 8.549 & 4.826 & 1.77 \\
\hline NC-1-1 & 0.8 & 11.169 & 7.653 & 1.46 \\
\hline NC-1-2 & 1.6 & 12.273 & 9.170 & 1.34 \\
\hline
\end{tabular}


The original Hawkins direct shear resistance model, as described in [6-9], and the modified static and impact direct shear models that were derived from the newly-obtained test data are defined in Table 4, and Figs. 5 and 6. The results for the $0 \%$ reinforcement are not addressed in this study, since the focus is on reinforced concrete structural elements.

Table 4. Direct Shear Models for NSC (see Fig. 3 for parameter definitions).

\begin{tabular}{|c|c|c|c|}
\hline & Original Hawkins [6-9] & Modified Static & Modified Impact \\
\hline$\tau_{\mathrm{e}}$ & $165+0.157 f_{c}^{\prime} \leq \tau_{m} / 2$ & $165+0.157 f_{c}^{\prime} \leq \tau_{m} / 2$ & NA \\
\hline$\tau_{m}$ & $8 \sqrt{f^{\prime}{ }_{c}}+0.8 \rho_{v t} f_{y}$ & $11 \sqrt{f^{\prime}{ }_{c}}+0.6 \rho_{v t} f_{y}$ & $1.5\left(11 f^{\prime}{ }_{c}\right.$ \\
\hline & & & $\left.+0.6 \rho_{v t} f_{y}\right)$ \\
\hline$\tau_{L}$ & $\frac{0.85 A_{s b} f_{s}^{\prime}}{A_{c}}$ & $\rho_{v t} f_{y} \quad \leq 0.008 f_{y}$ & $\rho_{v t} f_{y} \leq 0.008 f_{y}$ \\
\hline$K_{e}$ & $\mathrm{O}$ to $\mathrm{A}\left(\tau_{\mathrm{e}}, \Delta_{1}\right)$ & $12 f^{\prime}{ }_{c}$ & NA \\
\hline$K_{c}$ & A to $\mathrm{B}\left(\tau_{\mathrm{m}}, \Delta_{2}\right)$ & $3.5 f^{\prime}{ }_{c}$ & $180 f^{\prime}{ }_{c}$ \\
\hline$K_{u}$ & $-2000-0.75 f_{c}^{\prime}$ & $-2000-0.75 f^{\prime}{ }_{c}$ & $\begin{array}{l}4 *(-2000 \\
\left.-0.75 f^{\prime}{ }_{c}\right)\end{array}$ \\
\hline$\Delta 1$ & 0.004 & $\tau_{e} / K_{e}$ & NA \\
\hline$\Delta_{2}$ & 0.012 & $\Delta_{1}+\left(\tau_{m}-\tau_{e}\right) / K_{c}$ & $\tau_{m} / K_{c}$ \\
\hline$\Delta 3$ & 0.024 & $\begin{array}{c}\Delta_{2}+\left[0.012\left(\frac{\rho_{v t}}{0.008}\right)\right] \\
\text { for } \rho_{\mathrm{vt}} \geq 0.8 \% \\
\text { and } \Delta_{2}+0.012 \\
\text { for } \rho_{\mathrm{vt}}=0\end{array}$ & $\Delta_{2}+0.012$ \\
\hline$\Delta 4$ & $\Delta_{3}+\left(\tau_{L}-\tau_{m}\right) / K_{u}$ & $\Delta_{3}+\left(\tau_{L}-\tau_{m}\right) / K_{u}$ & $\Delta_{3}+\left(\tau_{L}-\tau_{m}\right) / K_{u}$ \\
\hline$\Delta_{\max }$ & $\begin{array}{c}\left(\frac{e^{x}-1}{120}\right), \\
\text { where } x=\frac{900}{2.86 \sqrt{\frac{f_{c}}{d_{b}}}}\end{array}$ & Bar diameter & Bar diameter \\
\hline
\end{tabular}

$* \mathrm{f}^{c}$ is obtained from tests on $\Phi 6 " \mathrm{X} 12 "(\Phi 150 \mathrm{~mm}$ X $300 \mathrm{~mm})$ cylinders.

All units are US Standard for comparison with the units used for the original Hawkins model. 


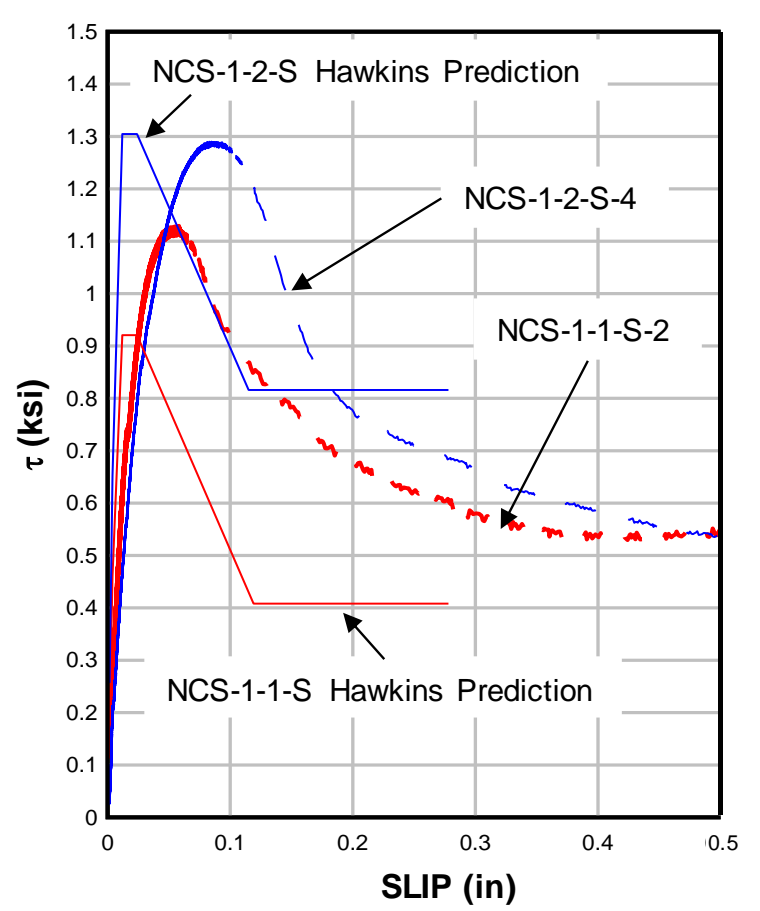

a. Original Hawkins

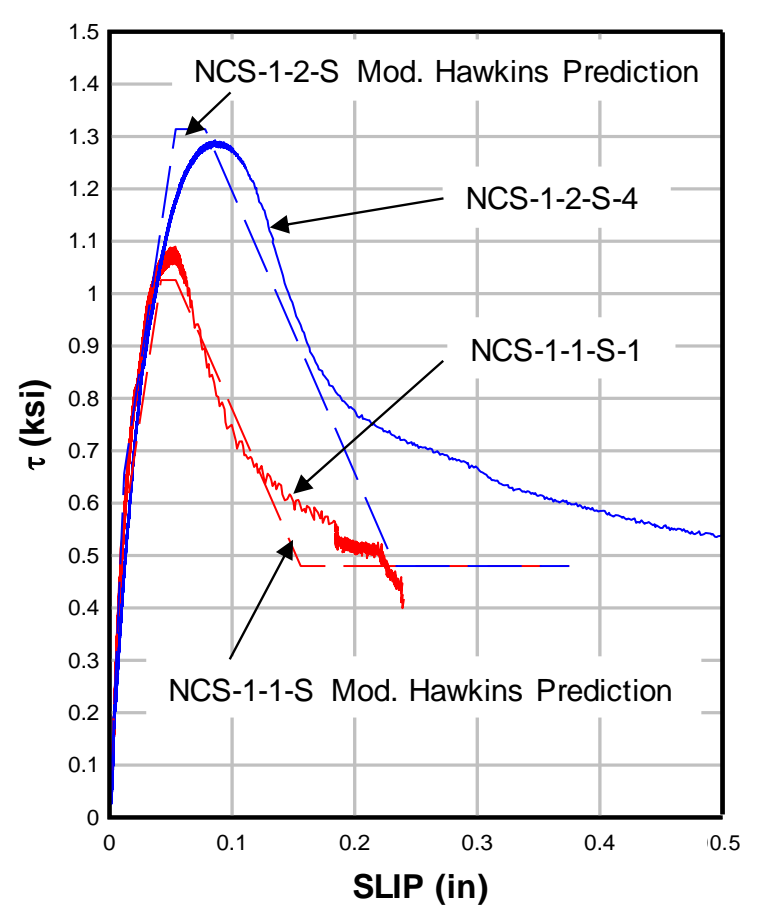

b. Modified Hawkins

Fig. 5: Original and modified Hawkins direct shear model compared to static test results [22].

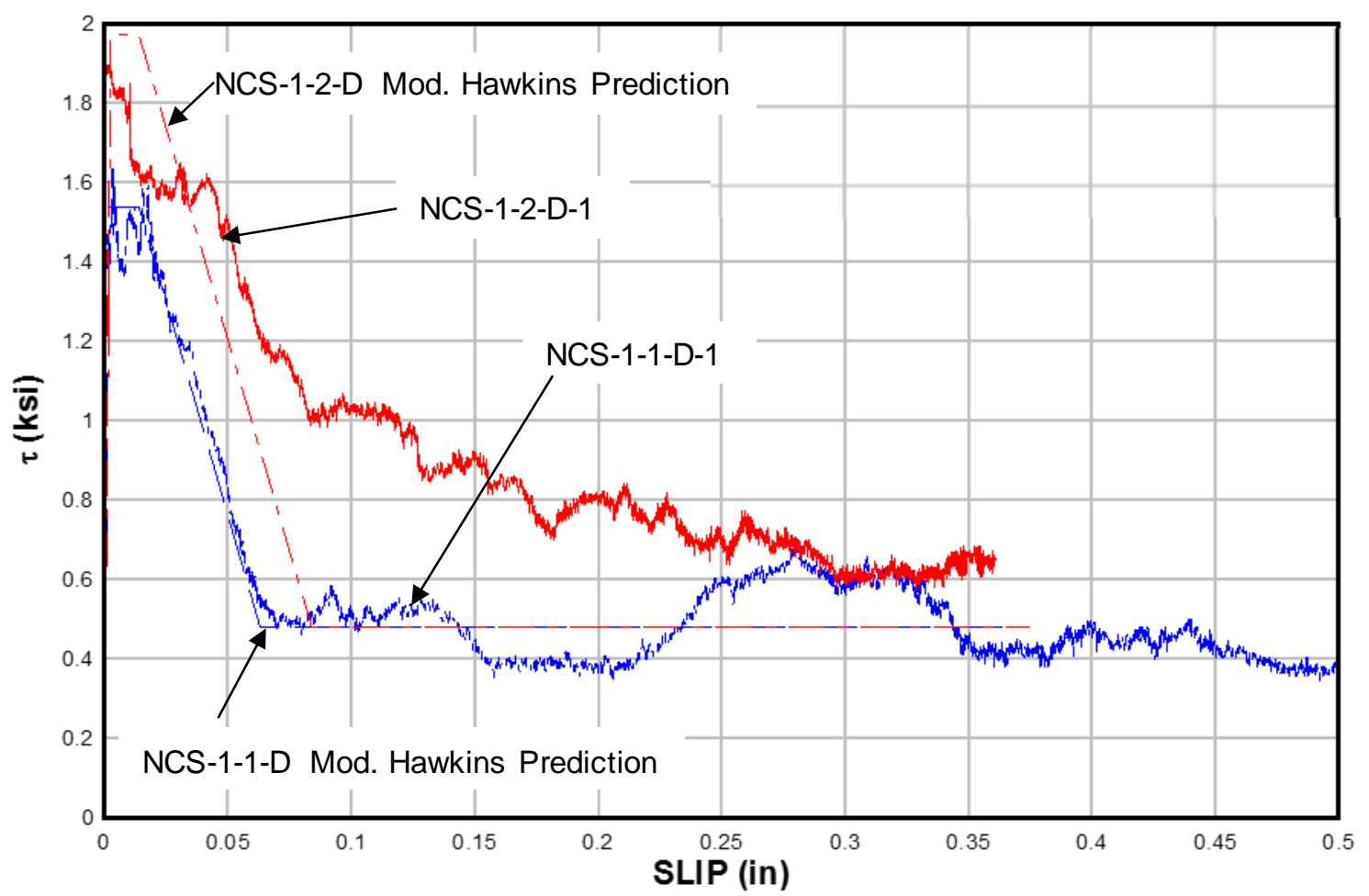

Fig. 6: Modified impact Hawkins model compared to test results [22]. 
The modified models for the static and impact loading domains were derived to approximate closely the observed experimental behaviors. The original Hawkins model (Fig. 3) utilized constant slip values for $\Delta_{1}, \Delta_{2}$, and $\Delta_{3}$, while for the modified models, the elastic slope $\left(\mathrm{K}_{\mathrm{e}}\right)$ and the post cracking slope $\left(\mathrm{K}_{\mathrm{c}}\right)$ were chosen to provide slips comparable to those observed experimentally. It should be noted that in the modified equations for the impact domain the segment between $\mathrm{O}$ and $\mathrm{B}$ is linear. As a result, the parameters $\tau_{e}, \mathrm{~K}_{\mathrm{e}}$, and $\Delta_{1}$ are no longer needed for the modified and impact direct shear models. Also, it was noted that the slip at a constant peak shear stress, $\tau_{m}$, varied with the amount of transverse steel reinforcement. The proposed equation for $\Delta_{3}$ replicates the results and modifies the slip at constant peak shear stress based on the reinforcement ratio. The slip at constant peak remained $\Delta_{2}+0.012$ for $0 \%$ reinforcement ratio for both static and impact loads. However, it was affected in the static domain by the amount of reinforcement. The maximum slip, $\Delta_{\max }$, was limited to the bar diameter of shear reinforcement since at this slip either the bars would have failed in shear, or rotated beyond the point where direct shear was applicable.

\section{Description of Previous Blast Tests for Direct Shear Model Validation}

Previous numerical simulations were performed in [16-21], and the results were compared with data obtained in field blast tests $[14,15]$. The tests in [14] were selected in the present study for the validation of the direct shear models described previously, herein. The test articles that were studied in [14] were shallow buried reinforced concrete boxes, as defined in Figs. 7 and 8, and in Table 5 (soil data were provided also in [26]). Tests FH1 and FH2 were conducted in a noncohesive sand backfill at a depth of burial (DOB) equal to $50 \%$ of the short clean span. Test FH3 was conducted in a sandy clay backfill at a depth of burial equal to $50 \%$ of the short clean span. Tests FH4 and FH5 were conducted in a non-cohesive sand backfill at a shallow depth of burial equal to $20 \%$ of the short clean span. Test FH6 was conducted in a sandy clay backfill 
at a depth of burial equal to $50 \%$ of the short clean span. The sandy clay backfill was wetted before the tests to ensure that the backfill would have a low shear strength.

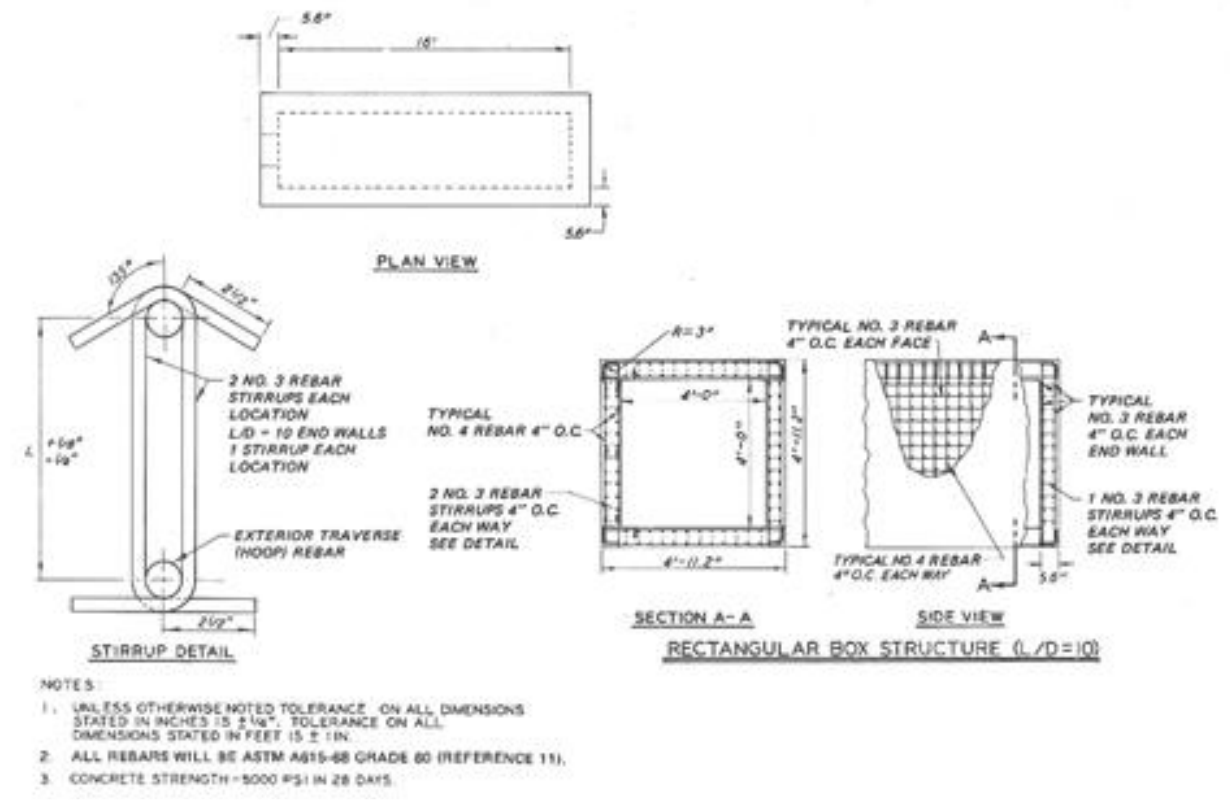

Fig. 7: Test Articles FH1 - FH4, and FH6 [14]
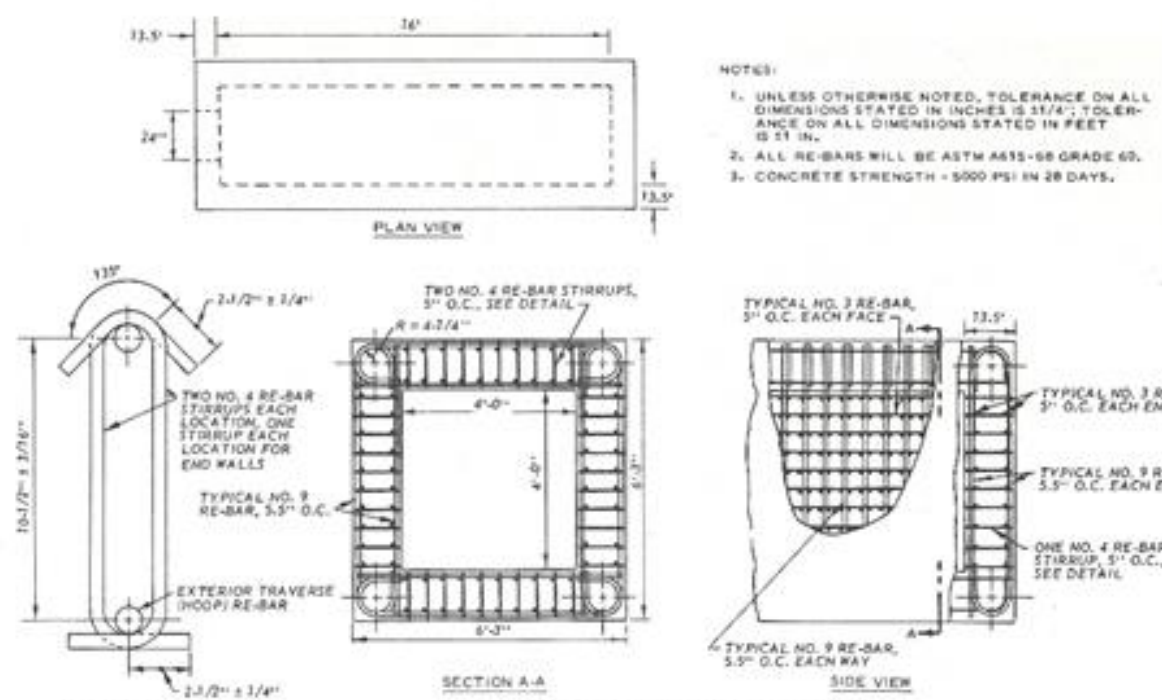

sectiok AA

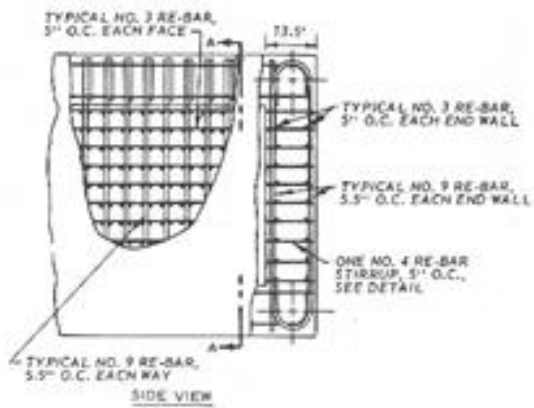
stanaup oetsaik

MECTANGULAR BOX STRUCTURE IL/D * A)

STRUCTURAL OETARLS ANO DLEENSIONS

Fig. 8: Test Articles FH5 [14] 
Table 5. Parameters for FH Tests [14, 26]

\begin{tabular}{|c|c|c|c|c|c|c|}
\hline Parameters & FH1 & $\mathrm{FH} 2$ & FH3 & FH4 & FH5 & FH6 \\
\hline $\begin{array}{l}\text { Height } \\
(\mathrm{mm})\end{array}$ & \multicolumn{6}{|c|}{1219} \\
\hline Ls (mm) & \multicolumn{6}{|c|}{1219} \\
\hline $\mathrm{L}_{\mathrm{L}}(\mathrm{mm})$ & \multicolumn{6}{|c|}{4877} \\
\hline $\begin{array}{l}\text { Thickness } \\
(\mathrm{mm})\end{array}$ & \multicolumn{4}{|c|}{142} & 343 & 142 \\
\hline $\begin{array}{l}\text { Span- } \\
\text { effective } \\
\text { depth ratio }\end{array}$ & \multicolumn{4}{|c|}{10} & 4 & 10 \\
\hline DOB $(\mathrm{mm})$ & \multicolumn{3}{|c|}{610} & \multicolumn{2}{|c|}{244} & 610 \\
\hline $\begin{array}{l}\text { DOB-Ls } \\
\text { ratio }\end{array}$ & \multicolumn{3}{|c|}{0.5} & \multicolumn{2}{|c|}{0.2} & 0.5 \\
\hline $\begin{array}{l}\mathrm{f}^{\prime} \mathrm{c}(\mathrm{MPa}), \\
\text { cylinder }\end{array}$ & 48.26 & 52.40 & 54.46 & 46.19 & 41.37 & 46.88 \\
\hline $\mathrm{fy}_{\mathrm{y}}(\mathrm{MPa})$ & 393.00 & 393.00 & 393.00 & 448.16 & 475.74 & 448.16 \\
\hline $\begin{array}{l}\text { Percentage } \\
\text { of steel }(\%)\end{array}$ & 1 & 1 & 1 & 1 & 1.5 & 1 \\
\hline Soil Type & Sand & Sand & Clay & Sand & Sand & Clay \\
\hline $\begin{array}{l}\text { wet/dry } \\
\text { density } \\
\left(\mathrm{kg} / \mathrm{m}^{3}\right)\end{array}$ & $1687 / 1634$ & $1698 / 1632$ & 1909/1496 & $1693 / 1623$ & NA/1634 & 1909/1496 \\
\hline $\begin{array}{l}\text { Unconfined } \\
\text { strength } \\
(\mathrm{kPa}) \\
\end{array}$ & NA & NA & 241 & NA & NA & 139 \\
\hline $\begin{array}{l}\text { Initial/max P } \\
\text { wave speed } \\
(\mathrm{m} / \mathrm{ms})\end{array}$ & \multicolumn{2}{|c|}{$0.512 / 1.234$} & $0.247 / 1.819$ & \multicolumn{2}{|c|}{$0.512 / 1.234$} & $0.247 / 1.819$ \\
\hline $\begin{array}{l}\text { Initial/max } \\
\text { S wave } \\
\text { speed } \\
(\mathrm{m} / \mathrm{ms}) \\
\end{array}$ & \multicolumn{2}{|c|}{$0.268 / 0.722$} & $0.109 / 0.109$ & \multicolumn{2}{|c|}{$0.268 / 0.722$} & $0.109 / 0.109$ \\
\hline $\begin{array}{l}\text { Friction } \\
\text { angle }\left({ }^{\circ}\right)\end{array}$ & \multicolumn{2}{|c|}{$30-36$} & $<15$ & \multicolumn{2}{|c|}{$30-36$} & $<15$ \\
\hline Cohesion & \multicolumn{6}{|c|}{0 , since the tests were conducted within days after backfill placement } \\
\hline $\begin{array}{l}\text { Charge } \\
\text { density } \\
\left(\mathrm{kg} / \mathrm{m}^{3}\right)\end{array}$ & 14.416 & 43.249 & 14. & & 57.666 & 28.833 \\
\hline
\end{tabular}

The airblast loads in [14] were applied to the soil free surface by employing the high explosive simulation technique (HEST) with the charge densities defined in Table 5, and the data recorded in those tests included surface blast pressures, interface pressures at various locations 
on the roof and side walls, and the post-test conditions of each structure. The test data in [14], and the previous numerical simulations in $[8,17-20]$ indicated that a direct shear failure occurred at about one millisecond after the load arrival, before any significant dynamic flexural response could be developed in the structural system. However, it was noted that if the roof slab survived that initial loading phase without failing in direct shear, the structural behavior was then dominated primarily by a flexural response without direct shear developing later.

It was shown in [22-25] that there were meaningful differences between the direct shear model that was based on the original model proposed by Hawkins [6] (and used in the previous numerical simulations in [7, 17-21]), and the direct shear models obtained in the recent precision impact tests, as defined in Table 4. Clearly, one has to wonder about the effects of using these direct shear models on numerical simulations of structural systems that may exhibit direct shear failures. For this reason, it was decided to reanalyze the test articles that were analyzed in [17-21] and tested in [14], and to examine the effects of direct shear models on the computed responses.

\section{Direct Shear Model Assessment by Numerical Analysis of Structural Field Tests}

The above-mentioned resistance models for direct shear behavior were incorporated into the fast-running computer program DSAS [27], and the program was used to reanalyze the buried RC roof slab cases that were reported in [14]. DSAS is a multifunctional single-degree-offreedom (SDOF) structural analysis program capable of modeling the response of a wide range of structural components under static or dynamic loads. The component library in DSAS includes reinforced concrete beams, columns, and joists, steel beams and columns, concrete masonry brick (CMU) and brick masonry walls, reinforced concrete slabs and boxes (either buried or above ground), wood panels, and simple or advanced mass-damper systems. The materials library includes either linear elastic or fully nonlinear models for steel (structural 
members and reinforcing bars), confined and unconfined normal strength concrete (NSC), ultra-high performance concrete (UHPC), CMU and brick walls, different geological materials, and user supplied materials options. Load options include a wide range of static, blast, and impact options (provided by the user or generated by embedded links to several blast simulation programs). DSAS can generate physics-based moment-curvature, and/or resistance (loaddeflection) functions for the included structural components. Besides time history analyses, it has the capability to also compute physics-based load-impulse (P-I) diagrams for any of the components mentioned above. DSAS can be used for both structural assessment and for iterative runs in support of protective design.

The peak structural resistance of an RC slab in the compression membrane mode can be enhanced by external in-plane compressive force. This also occurs in the roof slabs of buried boxes, due to a horizontal component of the vertical stress in the soil, as described in $[17,21]$. The horizontal soil pressure pulse is derived by multiplying the vertical soil pressure pulse by the factor $\mathrm{K}_{\mathrm{h}}$, whose value is 1 for clay and 0.5 for dry sand. For the box-type structures under consideration, the in-plane compressive forces are induced by the horizontal component of the pressure pulse that propagates vertically through the soil from the airblast load on the surface, as shown in Fig. 9. Since these compressive forces vary with time, as the soil-structure interface pressure pulses travel along the vertical walls, one has to calculate their magnitudes at every time step of the analysis. Accordingly, the roof slabs were represented by their structural resistance functions, that included both compression and tension membrane actions that varied with the variation of the externally-induced in-plane compression. 

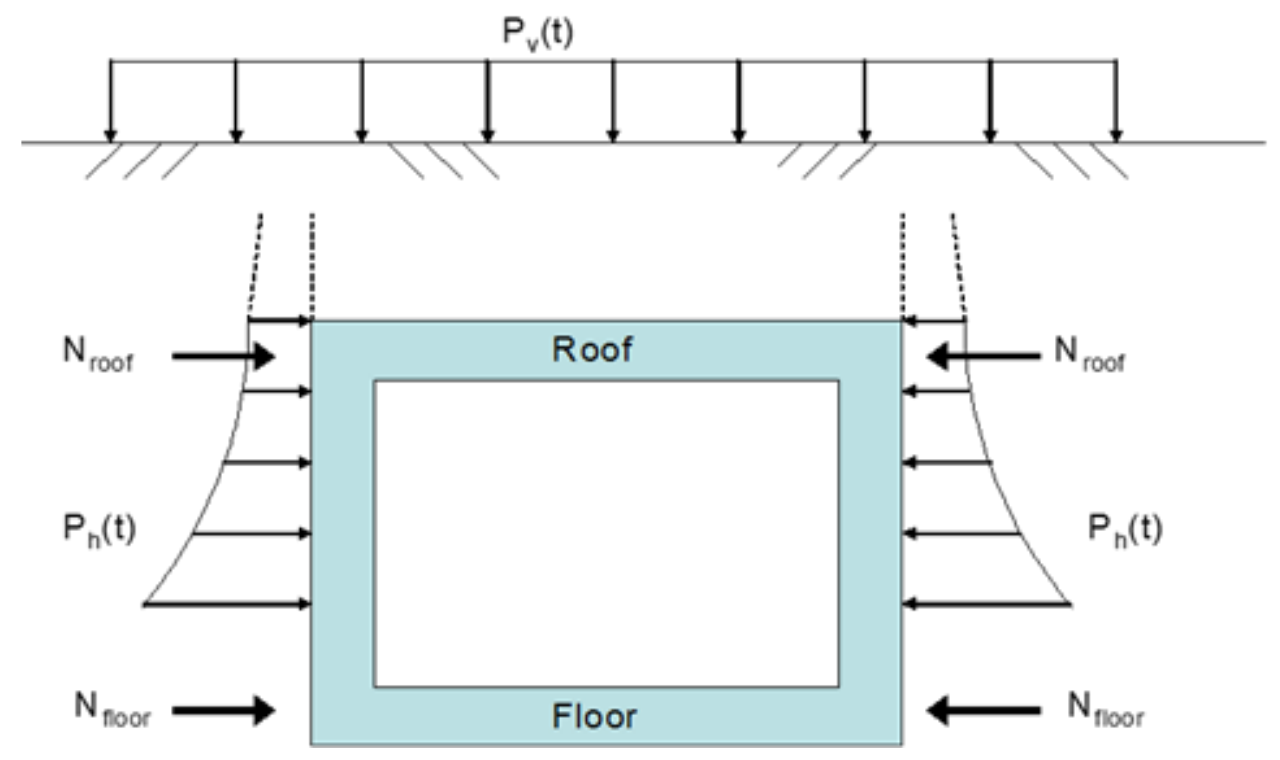

Fig. 9: Model for externally applied in-plane thrust [17,21].

The dynamic reactions at the roof slab supports were used to drive the direct shear effects. As discussed in [17-21], one can loosely couple the direct shear and flexural responses, since direct shear may occur only very early during the structural response (e.g., within about $1 \mathrm{~ms}$ after the load arrival), while the flexural behavior will occur at later times. As noted earlier, herein, the cases tested in [14] were reanalyzed for this assessment, using modifications that were developed in [21], as follows:

- The effective mass of both the structural roof and the soil cover varied with changes in the roof's deflection.

- The pressure distribution on the roof was affected by the roof's deflection and soil arching.

- The stress wave propagation in the soil was used to address the dynamically-variable lateral pressure on the walls for computing the thrust in the roof slab.

- The loading rate effects on concrete and steel were included.

- Strain hardening of reinforcements was included in the material model for steel. 
Two sets of dynamic analyses were conducted for each of the roof slabs of the buried RC boxes, as follows: One set of analyses used the earlier enhanced direct shear model that was used previously in [17-21], based the original Hawkins model (first column in Table 4, and Fig. 3). The enhancement by a factor of 1.4 represented the combined effects of compression perpendicular to the direct shear plane and rate effects, as recommended in [17]. The second set of analyses was carried out with the modified direct shear model for impact conditions, as defined by the third column of Table 4 . Beside the differences between the direct shear models for the dynamic analyses, all other input parameters were identical. The damping ratio for the flexural analyses was assumed to be equal to $20 \%$ (the flexural response induced soil-structure interaction effect that is represented by a higher damping ratio, as discussed in [17-21]). Since the direct shear response is governed by a sudden downward motion of the roof slab that is not affected by a soil-structure interaction, the damping ratio used for direct shear in these analyses was only $5 \%$. The dynamic increase factors for the materials were determined assuming a constant strain rate of 0.1 , and a parametric study with higher strain rates showed little or no difference in the results.

\section{Results and Discussion}

The computer code DSAS [27] was used in this study for the dynamic analysis of roof slabs in shallow-buried RC box-type structures subjected to airblast-induced ground shock loadings. This computational approach was used to compare the effects of two direct shear models on the numerical outcome. The numerical results obtained previously for these roof slabs [17-21] were compared with the new results that were based on using the modified direct shear model for impact loads obtained in [22], as defined in Table 4. The numerical data obtained for both types of direct shear models were compared to the available test results from [14], as shown in Table 6, and the findings were also used for the code validation for the various computational aspects of DSAS. 
Table 6. Summary of Results

(Converted to SI from US Standard units reported in [14])

\begin{tabular}{|c|c|c|c|c|c|c|c|c|c|c|c|c|c|}
\hline \multicolumn{4}{|c|}{ Test Data [1] } & \multicolumn{5}{|c|}{$\begin{array}{c}\text { Dynamic Analysis with Enhanced Original } \\
\text { Hawkins Direct Shear Model }\end{array}$} & \multicolumn{5}{|c|}{$\begin{array}{c}\text { Dynamic Analysis with Impact Direct Shear } \\
\text { Model }\end{array}$} \\
\hline Test & $\begin{array}{c}\text { Observed } \\
\text { Roof } \\
\text { Behavior }\end{array}$ & $\begin{array}{l}\text { Average } \\
\text { Peak } \\
\text { Pressure } \\
(\mathrm{MPa})\end{array}$ & $\begin{array}{l}\text { Measured } \\
\text { Permanent } \\
\text { Deflection } \\
\Delta_{1}(\mathrm{~mm})\end{array}$ & $\begin{array}{r}\text { Numerical } \\
\text { Behavior }\end{array}$ & $\begin{array}{c}\text { Computed } \\
\text { Permanent } \\
\text { Deflection } \\
\Delta_{2}(\mathrm{~mm})\end{array}$ & $\frac{\Delta_{2}}{\Delta_{1}}$ & $\begin{array}{c}\text { Failure } \\
\text { Direct } \\
\text { Shear } \\
\text { Slip } \\
(\mathrm{mm})\end{array}$ & $\begin{array}{c}\text { Failure } \\
\text { Time } \\
\text { (msec) }\end{array}$ & $\begin{array}{r}\text { Numerical } \\
\text { Behavior }\end{array}$ & $\begin{array}{r}\text { Computed } \\
\text { Permanent } \\
\text { Deflection } \\
\Delta_{2}(\mathrm{~mm})\end{array}$ & $\frac{\Delta_{2}}{\Delta_{1}}$ & $\begin{array}{c}\text { Failure } \\
\text { Direct } \\
\text { Shear } \\
\text { Slip } \\
(\mathrm{mm})\end{array}$ & $\begin{array}{c}\text { Failure } \\
\text { Time } \\
(\mathrm{msec})\end{array}$ \\
\hline FH1 & Flexure & 16.547 & 11.2 & Flexure & 12.7 & 1.13 & -- & -- & Flexure & 10.4 & 0.93 & -- & -- \\
\hline $\mathrm{FH} 2$ & $\begin{array}{l}\text { Direct } \\
\text { Shear }\end{array}$ & 35.853 & Collapsed & $\begin{array}{l}\text { Direct } \\
\text { Shear }\end{array}$ & Collapsed & 1.00 & 5.1 & 1.1 & $\begin{array}{l}\text { Direct } \\
\text { Shear }\end{array}$ & Collapsed & 1.00 & 4.0 & 0.95 \\
\hline FH3 & Flexure & 18.271 & 152.4 & Flexure & 149.9 & 0.98 & -- & -- & Flexure & 146.0 & 0.96 & -- & -- \\
\hline FH4 & Flexure & 20.684 & 317.5 & Flexure & 289.6 & 0.91 & -- & -- & Flexure & 292.1 & 0.92 & -- & -- \\
\hline FH5 & Shear & 124.106 & 78.7 & $\begin{array}{l}\text { Flexure - } \\
\text { Dia. Shear }\end{array}$ & 86.4 & 1.1 & -- & -- & $\begin{array}{l}\text { Flexure - } \\
\text { Dia. Shear }\end{array}$ & 87.1 & 1.1 & -- & -- \\
\hline FH6 & $\begin{array}{l}\text { Direct } \\
\text { Shear }\end{array}$ & 57.364 & Collapsed & $\begin{array}{l}\text { Direct } \\
\text { Shear }\end{array}$ & Collapsed & 1.00 & 5.8 & 1.2 & $\begin{array}{l}\text { Direct } \\
\text { Shear }\end{array}$ & Collapsed & 1.00 & 4.5 & 1.03 \\
\hline
\end{tabular}


The results in Table 6 show that only cases FH 2 and FH 6 exhibited direct shear failures at about $1 \mathrm{~ms}$ after the load arrival. All other cases exhibited flexural behaviors. Nevertheless, it was noted in both the test and simulations that case FH 5 exhibited also diagonal shear damage. One should note from Table 5 that case FH 5 was a deep slab that had a span-to-effective depth ratio of 4 , while all other roof slabs were slender with span-to-effective depth ratios of 10 . Therefore, the combined flexure and diagonal shear response of case FH 5 is to be expected in such deep members, and this combined response was fully captured by DSAS through a diagonal shear reduction algorithm [28]. It is noted that when the original direct shear model was used, the computed-to-measured peak displacements ratio varied between 0.91 and 1.13 , with an average 1.02. However, when the modified impact direct shear model was used, the computed-to-measured peak displacements ratio varied between 0.92 and 1.1 , with an average of 0.985 . Although the average of the displacement results shifted from 1.02 to 0.985 , the general behaviors remained virtually the same in both sets of analyses.

Changing the direct shear models did not change the structural response type, and the differences in residual displacement magnitudes were reasonably small. Another difference was noticed in the direct shear failure slip, and the time at which it occurred. It was noted for Test FH 2 that the old model predicted a failure slip of $5.1 \mathrm{~mm}$ at $1.1 \mathrm{~ms}$, while the new direct shear model predicted a failure slip of $4 \mathrm{~mm}$ at $0.95 \mathrm{~ms}$. A difference of $1.1 \mathrm{~mm}$ and $0.15 \mathrm{~ms}$ in such an analysis is both insignificant and very reasonable. For Test FH 6 the old model predicted a failure slip of $5.8 \mathrm{~mm}$ at $1.2 \mathrm{~ms}$, while the new direct shear model predicted 4.5 $\mathrm{mm}$ at $1.03 \mathrm{~ms}$. Again, a difference of $1.3 \mathrm{~mm}$ and $0.17 \mathrm{~ms}$ in such an analysis is insignificant and quite reasonable. 


\section{Summary and Conclusions}

Direct shear is a known response mechanism in RC slabs subjected to blast loads that may cause their sudden and catastrophic failure. The empirical resistance functions for direct shear in RC elements under static loads that were introduced in the 1970s were based on limited test data, and insufficient knowledge on direct shear in the short-duration dynamic domain. Recent direct shear precision impact tests were conducted on RC shear specimens with three reinforcement ratios, and the results were used to derive modified direct shear resistance functions that were notably different from the original resistance functions. This provided an opportunity to assess if the new resistance functions could accurately represent the behavior RC structural elements subjected blast loads, and to understand the behavioral differences in the numerical simulations that could be associated with the two resistance functions. The numerical simulation results were compared also with data from field blast tests on buried RC box-type structures. Accordingly, the following conclusions can be drawn from this study:

- The numerical results obtained with the same computer code and the two direct shear models were very close to each other, and approximated well the experimental data. The noted very small differences between the numerical results were in the magnitudes of the peak displacements, and the time at which they occurred.

- Both direct shear models provided reasonably accurate representations of the observed structural responses for the tested structural systems, since the differences in $\tau_{\mathrm{m}}$, and $\Delta_{3}$ between the direct shear models were small.

- $\quad$ Direct shear in the dynamic and/or impact domains are affected primarily by the peak direct shear strength, $\tau_{\mathrm{m}}$, and the slip, $\Delta_{3}$, to cause direct shear strength softening. These parameters determine if and when a direct shear failure may occur. 
- The proposed numerical methodology can be employed successfully for the expedient and accurate analyses of RC slabs and box-type structural systems subjected to blast loads.

- The analyses that were based on rational models for structural behavior mechanisms have been validated with good accuracy and consistency.

- $\quad$ The proposed variation of the load and mass transformation factors for the SDOF system enabled reliable approximations of the observed structural responses under different loading combinations.

\section{Recommendations}

The findings from this study highlight the complexity of the direct shear phenomenon, and that additional data are needed to develop a comprehensive understanding of such behavior. Furthermore, it is important to study direct shear in other construction materials, such as ultrahigh performance concrete (UHPC) and ultra-high performance fiber reinforced concrete (UHPFRC). Such studies have been undertaken at the Center for Infrastructure Protection and Physical Security (CIPPS), and the results will be published in the near future.

\section{Acknowledgements}

The authors acknowledge the generous support for these studies from the Defense Threat Reduction Agency (DTRA), the US Army Engineer Research and Development Center (ERDC), and the Canadian Forces.

\section{REFERENCES}

1. Wight, J.K., and MacGregor, J.G., "Reinforced Concrete Mechanics and Design," $6^{\text {th }}$ Edition, Prentice Hall, Pearson, 2012.

2. Hofbeck, J.A., Ibrahim, I.O., and Mattock, A.H., "Shear Transfer in Reinforced Concrete," ACI Journal, February 1969, pp. 119-128. 
3. Mattock, A.H., and Hawkins, N.M., "Shear Transfer in Reinforced Concrete - Recent Research,” PCI Journal, Vol. 17, No. 2, pp. 55-75, 1972.

4. Hawkins, N.M., "The strength of stud shear connections," Civil Engineering Transactions, IE, Australia, pp. 39-45, 1974.

5. Park, R., and Paulay, T., "Reinforced Concrete Structures," Section 7.8, WileyInterscience, 1975.

6. Hawkins, N., "Dynamic Shear Resistance of Reinforced Concrete,", Letter Report to U.S. Navy, 28 August 1981.

7. Crawford, J.E., Johnson, F., Hughes, T.J.R., Murtha, R., and Wagner, P., "Predictions of Failure Loads and Modes for Magazine Structures," Report No. TM-51-81-13, Naval Civil Engineering Laboratory, Port Hueneme, CA, Nov. 1981.

8. Crawford, J. E., Holland, T.J., Mendoza, P.J. and Murtha, R., "A Failure Methodology Based on Shear Deformation," Proc. Fourth ASCE Engineering Mechanics Division Specialty Conference, Purdue University, Lafayette, IN, 1983.

9. Crawford, J. E., Krauthammer, T., Karagozian, J. and Hinman, E., "Structural Components - Analysis and Design Examples," in "Structural Design for Physical Security: State of The Practice," Chapter 4, ASCE, SEI, Reston, VA, 1999.

10. Walraven, J.C., Reinhardt, H.W., "Theory and Experiments on the Mechanical Behaviour of Cracks in Plain and Reinforced Concrete Subjected to Shear Loading," Heron, vol. 26, No. 1A, 1981.

11. Valle, M., and Buyukozturk, O., "Behavior of Fiber Reinforced High-Strength Concrete under Direct Shear,” ACI Materials J., pp. 122-133, March-April 1993.

12. Louw, J.M., Koch, B.C., and Koen, F.J., "Direct shear strength of concrete under impact," Transactions on the Built Environment, Vol. 8, WIT Press, 1994.

13. Ali, M.A., and White, R.N., "Enhanced Contact Model for Shear Friction of Normal and High-Strength Concrete," ACI Structural Journal, Vol. 96, No. 3, May-June 1999.

14. Kiger, S.A., and Getchell, J.V., "Vulnerability of Shallow-Buried Flat Roof Structures," Technical Report SL-80-7, five parts, U.S. Army Engineer Waterways Experiment Station, Vicksburg, Miss, 1980-1982.

15. Slawson, T. R., "Dynamic Shear Failure of Shallow-Buried Flat-Roofed Reinforced Concrete Structures Subjected to Blast Loading," Technical Report SL-84-7, U.S. Army Engineer Waterways Experiment Station, Vicksburg, Miss, 1984.

16. T. J. Ross, "Direct Shear Failure in Reinforced Concrete Beams Under Impulsive Loading," Technical Report AFWL-TR-83-84, Air Force Weapons Laboratory, Kirtland Air Force Base, NM, 1983. 
17. Krauthammer, T., Bazeos, N., and Holmquist, T.J., "Modified SDOF Analysis of RC BoxType Structures.” ASCE, Journal of Structural Eng., Vol. 112, No. 4, pp. 726-744, 1986.

18. Krauthammer, T., Assadi-Lamouki, A., and Shanaa, H.M., "Analysis of Impulsively Loaded RC Structural Elements, Part 1 - Theory," Computers and Structures, Vol. 48, No. 5, pp. 851-860, September 1993.

19. Krauthammer, T., Assadi-Lamouki, A., and Shanaa, H.M., "Analysis of Impulsively Loaded RC Structural Elements, Part 2 - Implementation," Computers and Structures, Vol. 48, No. 5, pp. 861-871, September 1993.

20. Krauthammer, T., Shaana, H.M., and Assaadi-Lamouki, A., "Response of Structural Concrete Structural Elements to Severe Impulsive Loads." Computer \& Structures, Vol. 53, No. 1, pp. 119-130, 1994.

21. Chee, K.H., and Krauthammer, T., and Astarlioglu, S., "Analysis of Shallow Buried Reinforced Concrete Box Structures Subjected to Airblast Loads," Final Report to U.S. Army ERDC, CIPPS-TR-002-2008, Center for Infrastructure Protection and Physical Security, University of Florida, May 2008.

22. French, R., Stone, M., Krauthammer, T., Kim, J., Bui, L., and Lavenhagen, D., "Assessment of Direct Shear Behavior in Normal-strength and Ultra-High Performance Concretes," Technical Report to DTRA, CIPPS-TR-008-2013, Center for Infrastructure Protection and Physical Security, University of Florida, September 2013.

23. French, R., Krauthammer, T., and Stone, M., "Direct Shear Behavior in Normal Strength and Ultra High Performance Concretes," Technical Report CIPPS-TR-001-2014, Center for Infrastructure Protection and Physical Security, University of Florida, May 2014.

24. Kim, J., Krauthammer, T., French, R., and Stone, M., "Frequency Domain Assessment of Direct Shear in NSC and UHPC," Technical Report CIPPS-TR-002-2014, Center for Infrastructure Protection and Physical Security, University of Florida, May 2014.

25. Maher, E., Krauthammer, and T., Stone, M., "Experimental Frequency Analysis of Direct Shear Behavior in Normal Strength and Ultra-High Performance Concretes," Technical Report CIPPS-TR-001-2015, Center for Infrastructure Protection and Physical Security, University of Florida, March 2015.

26. Windham, J.E., "Finite Element Calculations of Foam HEST 1," Technical Report SL-801, U.S. Army Engineer Waterways Experiment Station, Vicksburg, Miss, April 1980.

27. Astarlioglu, S., and Krauthammer, T., "Dynamic Structural Analysis Suite (DSAS)," User Manual, Version 4.0, Center for Infrastructure Protection and Physical Security, University of Florida, 2012.

28. Krauthammer, T., Shahriar, S., and Shanaa, H. M., "Analysis of Reinforced Concrete Beams Subjected to Severe Concentrated Loads," Structural Journal, ACI, Vol. 84, No. 6, pp. 473-480, November-December 1987. 